\title{
KESESUAIAN DAN DAYA DUKUNG EKOWISATA BERBASIS EKOLOGI MANGROVE DI TELUK PANGPANG, BANYUWANGI
}

\author{
Lilik Rodiana $^{\mathrm{a} *}$, Fredinan Yulianda ${ }^{\mathrm{b}}$, Sulistiono ${ }^{\mathrm{b}}$ \\ ${ }^{a}$ Program Studi Pengelolaan Sumberdaya Pesisir dan Lautan, Sekolah Pascasarjana Institut Pertanian Bogor, \\ Kampus IPB Dramaga Bogor 16680, Indonesia. \\ ${ }^{\mathrm{b}}$ Departemen Manajemen Sumberdaya Peraiaran, Fakultas Perikanan dan Ilmu Kelautan, Institut Pertanian \\ Bogor, Kampus IPB Dramaga Bogor 16680, Indonesia. \\ *Koresponden penulis : rodiana.17@gmail.com
}

\begin{abstract}
Abstrak
Kawasan mangrove Teluk Pangpang merupakan hasil rehabilitasi yang dilakukan sejak tahun 2000. Saat ini luas seluruh kawasan mangrove 571.6 hektar. Tingginya biodiversitas di kawasan mangrove berpotensi untuk dikembangkan sebagai kawasan ekowisata. Tujuan penelitian ini adalah menghitung indeks kesesuaian dan daya dukung kawasan di ekosistem mangrove Teluk Pangpang. Penelitian dilakukan pada bulan Desember 2017 sampai Februari 2018 dengan delapan titik stasiun pengamatan. Kesesuaian ekowisata mangrove mempertimbangkan lima parameter yaitu ketebalan mangrove, kerapatan mangrove, jenis mangrove, pasang surut, dan Objek biota. Hasil penelitian menunjukkan kesesuaian ekowisata berdasarkan parameter ekologis dalam kategori sesuai dan tidak sesuai. Panjang area yang dapat dimanfaatkan untuk kegiatan tracking adalah 169.23 meter dengan daya dukung 339 orang/hari.
\end{abstract}

Kata Kunci : Banyuwangi, daya dukung, ekowisata mangrove, kesesuaian kawasan, Teluk Pangpang

\begin{abstract}
The mangrove area in Pangpang Bay is a result of mangrove rehabilitation since 2000 and had been growth into $572.6 \mathrm{Ha}$ in wide. This mangrove ecosystem has a potency to develope as an ecotourism area. The aime of the research is to calculate the compatibility index and carrying capacity of the ecosystem in Pangpang Bay. This research was conducted from December 2017 to February 2018 with 8 stations of observation. The suitability of the mangrove ecotourism is taken by considering five parameters such as the mangrove thickness, mangrove density, species of mangrove, tides, and objects of biota. Results of this research reveal that the suitability of this area for ecotourism based on ecological parameters is suitable and not suitable. The total of the mangrove area in this bay that can be use for tracking activity is around 169.23 meters long for 339 people per day.
\end{abstract}

Keywords: Banyuwangi, carrying capacity, mangrove ecotourism, area suitability, Pangpang Bay

\section{PENDAHULUAN}

Mangrove sebagai tumbuhan berkayu maupun bersemak belukar yang menempati habitat antara daratan dan laut yang secara periodik digenangi air pasang. Mangrove memberikan manfaat ekologi yang penting sebagai tempat pemijahan (spawning grounds), tempat pengasuhan (nursery grounds) dan tempat mencari makan (feeding grounds) berbagai jenis ikan, udang, kepiting dan biota laut lainnya. Mangrove juga berfungsi sebagai penghalang badai seperti gelombang tinggi, angin topan dan tsunami. Selain manfaat ekologis, keberadaan ekosistem mangrove dapat dimanfaatkan masyarakat pesisir untuk menangkap biota laut tersebut ataupun dimanfaatkan sebagai objek daya tarik wisata alam [1]; [2]; [3]; [4]; [5].

Teluk Pangpang merupakan salah satu wilayah pesisir yang memiliki sumber daya mangrove di Kabupaten Banyuwangi. Pada tahun 1989 wilayah bagian barat Teluk Pangpang memiliki luas mangrove sebesar \pm 207.5 Ha dan mengalami pertambahan luasan menjadi \pm 282.8 Ha pada tahun 2011 , luas seluruh kawasan mangrove saat ini sebesar 571.68 Ha. Pertambahan luas mangrove tersebut adalah hasil dari rehabilitasi yang 
dilakukan sejak tahun 2000. Kawasan mangrove Teluk Pangpang ditetapkan sebagai salah satu ekosistem esensial di Indonesia, karena merupakan satu-satunya kawasan mangrove yang tersisa di pantai timur Provinsi Jawa Timur. Kawasan mangrove ini memiliki luasan dan keanekaragaman flora dan fauna yang cukup baik. Di kawasan mangrove ini terdapat berbagai spesies mangrove dan spesies burung yang dilindungi dan terancam punah. [6]; [7]; [8]; [5].

Tingginya keanekaragaman biota yang berasosiasi dengan mangrove dan beragamnya jenis mangrove di kawasan ini membuatnya berpotensi untuk dikembangkan sebagai kawasan wisata. Pengembangan kawasan wisata dengan konsep ekowisata merupakan salah satu perjalanan wisata alam yang berorientasi pada konservasi, dan melestarikan sumber daya yang berkelanjutan. Untuk mendukung kegiatan pengembangan ekowisata perlu menggali potensi keanekaragaman flora dan fauna yang menjadi prioritas dalam pengembangan ekowisata, semakin tinggi potensi daya tarik kawasan akan semakin menarik minat pengunjung untuk berkunjung di kawasan tersebut. Dengan melibatkan masyarakat lokal ke dalam pengelolaan ekowisata akan lebih menjamin keberlanjutan rehabilitasi dan konservasi mangrove serta memberikan manfaat lebih terkait peningkatan perekonomian masyarakat [10]; [11]; [12]; [13]; [14].

Pengembangan ekowisata membutuhkan penilaian potensi keanekaragaman flora fauna di ekosistem mangrove berdasarkan parameter kesesuaian ekologis dan daya dukung kawasan. Penilaian kesesuaian ekologis yaitu untuk meminimalkan dampak dari kegiatan ekowisata. Perhitungan daya dukung kawasan digunakan untuk mengetahui jumlah maksimal pengunjung yang secara fisik dapat ditampung dalam satu hari pada waktu tertentu tanpa menimbulkan dampak negatif pada sumber daya alam maupun manusia [15]; [16]; [17]. Berdasarkan uraian tersebut, penelitian ini bertujuan untuk mengkaji potensi mangrove, kesesuaian dan daya dukung kawasan untuk pengembangan ekowisata di Teluk Pangpang Banyuwangi.

\section{MATERI DAN METODE}

\section{Tempat dan Waktu Penelitian}

Penelitian dilaksanakan di ekosistem mangrove Teluk Pangpang, Kabupaten Banyuwangi, Provinsi Jawa Timur, pada bulan Desember 2017 hingga Februari 2018. Pengambilan sampel dibagi menjadi delapan stasiun (Gambar 1). Penentuan stasiun pengamatan menggunakan metode pengambilan secara sengaja (purposive sampling).

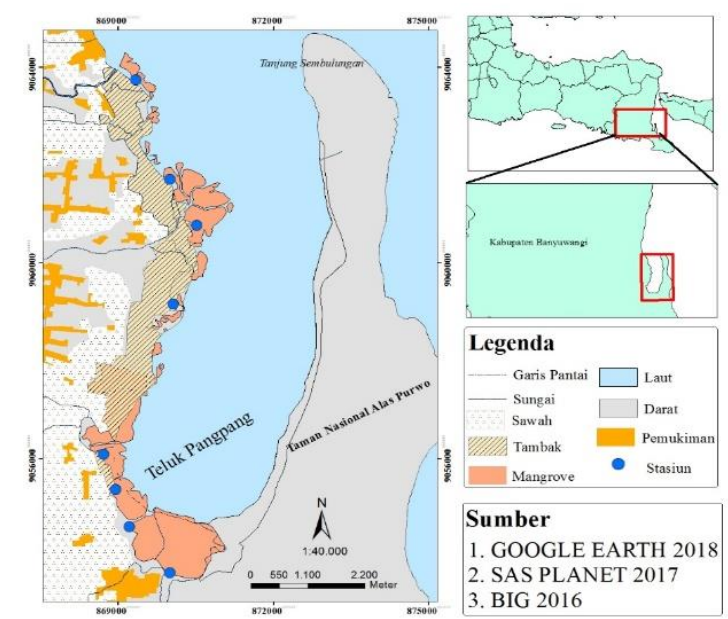

Gambar 1. Peta lokasi penelitian

\section{Pengumpulan Data}

Data yang dikumpulkan meliputi kondisi mangrove, sebaran mangrove dan sebaran biota yang berasosiasi dengan mangrove. Pengambilan sampel mangrove dilakukan menggunakan metode petak ganda dengan menggunakan banyak petak contoh yang letaknya tersebar merata. Peletakan petak contoh dilakukan secara acak (simple random sampling) [18], identifikasi jenis mangrove mengacu pada [19]. Cara peletakan petak contoh (Gambar 2).

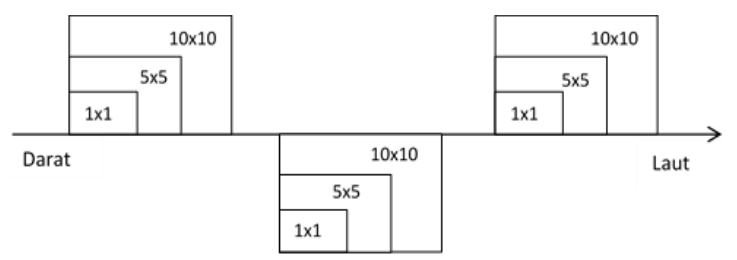

Gambar 2. Peletakan petak contoh pada 
pengambilan sampel mangrove

\section{Analisis Data}

\section{Analisis kerapatan mangrove}

Data yang dikumpulkan meliputi: jenis spesies, jumlah individu dan diameter pohon. Data-data tersebut kemudian diolah untuk mengetahui kerapatan setiap spesies dan kerapatan total semua spesies [20].

a. Kerapatan spesies adalah jumlah individu spesies i dalam suatu unit area yang dinyatakan dalam rumus:

$$
\mathrm{K}=\frac{\mathrm{ni}}{\mathrm{A}}
$$

b. Kerapatan total adalah jumlah semua individu mangrove dalam suatu unit area yang dinyatakan dalam rumus:

$$
\begin{aligned}
& \mathrm{KT}=\frac{\sum \mathrm{n}}{\mathrm{A}} \\
& \text { Keterangan: } \\
& \mathrm{K} \quad=\text { Kerapatan jenis } \mathrm{i} \\
& \mathrm{KT}=\text { Kerapatan total }
\end{aligned}
$$

A = Luas total area pengambilan contoh (luas petak contoh)

ni = Jumlah total individu dari jenis i

$\Sigma \mathrm{n}=$ Jumlah total tegakan seluruh jenis

\section{Analisis kesesuaian ekowisata}

Kategori wisata mangrove mempertimbangkan lima parameter dengan dua klasifikasi penilaian (Tabel 1).

$\mathrm{IKW}=\Sigma\left(\frac{N i}{N m a k s}\right) \times 100 \%$

\section{Keterangan:}

Nilai maksimum $=39$

IKW = Indeks kesesuaian wisata mangrove

S1 = Sesuai $(50 \%-100 \%)$

S2 $=$ Tidak sesuai $(<25 \%-49 \%)$

\begin{tabular}{|c|c|c|c|c|}
\hline No & Parameter & Bobot & Kategori & Skor \\
\hline \multirow[t]{4}{*}{1} & Ketebalan mangrove $(\mathrm{m})$ & 5 & $>500$ & 3 \\
\hline & & & $>200-500$ & 2 \\
\hline & & & $50-200$ & 1 \\
\hline & & & $<50$ & 0 \\
\hline \multirow[t]{4}{*}{2} & Kerapatan mangrove $\left(100 \mathrm{~m}^{2}\right)$ & 3 & $>15-20$ & 3 \\
\hline & & & $>10-15$ & 2 \\
\hline & & & $5-10$ & 1 \\
\hline & & & $<5$ & 0 \\
\hline \multirow[t]{4}{*}{3} & Jenis mangrove & 3 & $>5$ & 3 \\
\hline & & & $3-5$ & 2 \\
\hline & & & $1-2$ & 1 \\
\hline & & & 0 & 0 \\
\hline \multirow[t]{4}{*}{4} & Pasang surut $(\mathrm{m})$ & 1 & $0-1$ & 3 \\
\hline & & & $>1-2$ & 2 \\
\hline & & & $>2-5$ & 1 \\
\hline & & & $>5$ & 0 \\
\hline \multirow[t]{4}{*}{5} & Objek biota & 1 & Ikan, udang, kepiting, moluska, reptil, burung & 3 \\
\hline & & & Ikan, udang, kepiting, moluska & 2 \\
\hline & & & Ikan, moluska & 1 \\
\hline & & & Salah satu biota air & 0 \\
\hline
\end{tabular}

$\mathrm{Ni} \quad=$ Nilai parameter ke-i (bobot $\mathrm{x}$ skor)

Nmaks $=$ Nilai maksimum dari suatu kategori wisata

Tabel 1. Matriks kesesuaian ekowisata mangrove

Sumber: Yulianda (2007) 
Analisis daya dukung

Potensi ekologis pengunjung ditentukan oleh kondisi sumberdaya dan jenis kegiatan wisata [15]. Perhitungan potensi ekologis (Tabel 2).

$\mathrm{DDK}=K \times \frac{L p}{L t} \times \frac{W t}{W p}$

Keterangan:

DDK = Daya dukung kawasan
$\mathrm{K}=$ Potensi ekologis pengunjung per satuan unit area

Lp = Luas area untuk panjang area yang dapat dimanfaatkan

Lt = Unit area untuk kategori tertentu

$\mathrm{Wt}=$ Waktu yang disediakan oleh kawasan untuk kegiatan wisata dalam satu hari

$\mathrm{Wp}=$ Waktu yang dihabiskan oleh pengunjung untuk setiap kegiatan tertentu.

Tabel 2. Potensi ekologis pengunjung

\begin{tabular}{ccccc}
\hline Jenis Kegiatan & $\begin{array}{c}\text { Jumlah } \\
\text { Pengunjung (K) }\end{array}$ & Unit area (Lt) & $\begin{array}{c}\text { Waktu yang } \\
\text { dibutuhkan (Wp) }\end{array}$ & $\begin{array}{c}\text { Total waktu } \\
\text { satu hari } \\
\text { (Wt) }\end{array}$ \\
\hline Tracking Mangrove & 1 & 50 meter & 3 & 6 \\
\hline
\end{tabular}

Sumber: Yulianda (2007)

\section{HASIL DAN PEMBAHASAN}

\section{Jenis dan Kerapatan Mangrove}

Terdapat sembilan jenis mangrove yang ditemukan yaitu dari famili Rhizophoraceae, Euphorbiaceae, Cobretaceae, dan Meliaceae. Spesies mangrove yang banyak ditemukan dan penyebarannya di sepanjang Teluk adalah Rhizophora mucronata, Rhizophora apiculata, dan Sonneratia alba (Tabel 3). Selain jenis mangrove sejati, juga ditemukan jenis mangrove ikutan yaitu Clerodendrum inerme.

Penelitian Sudarmadji dan Indarto tahun 2011 ditemukan tujuh jenis mangrove di Teluk Pangpang yaitu Bruguiera gymnorrhiza, Ceriops tagal, Excoecaria agallocha, Rhizophora apiculata, Rhizophora mucronata, Rhizophora stylosa, dan Sonneratia alba [21]. Spesies Rhizophora stylosa tidak ditemukan pada stasiun penelitian. Sedangkan pada penelitian Buwono tahun 2017 terdapat spesies mangrove yang tidak ditemukan pada stasiun penelitian yaitu Avicennia marina [22]. Tidak ditemukannya kedua jenis mangrove tersebut diduga lokasi stasiun penelitian berbeda pada masing-masing peneliti.

Kerapatan jenis mangrove menunjukkan kelimpahan jenis di suatu ekosistem mangrove. Kerapatan jenis mangrove pada lokasi penelitian memiliki nilai kerapatan yang berbeda-beda (Tabel 4). Kerapatan tertinggi pada stasiun 3 yaitu $18 \mathrm{ind} / 100 \mathrm{~m}^{2}$ dan kerapatan terendah pada stasiun 4 yaitu 10 ind $/ 100 \mathrm{~m}^{2}$. Stasiun 3 dan stasiun 4 merupakan kawasan mangrove hasil rehabilitasi, tetapi stasiun 3 berada di muara sungai dan jauh dari kegiatan aktivitas masyarakat. Sedangkan stasiun 4 dekat dengan pemukiman penduduk, sebagai tempat parkir perahu nelayan dan adanya kegiatan tambak budidaya udang sehingga pertumbuhan mangrove pada kedua stasiun berbeda.

Penyebaran jenis mangrove yang tidak merata di lokasi penelitian dikarenakan pada beberapa titik stasiun seperti stasiun 1 sampai dengan stasiun 4 yang berlokasi di Kecamatan Muncar merupakan mangrove hasil rehabilitasi yang dilakukan oleh pemerintah daerah, instansi terkait maupun pihak swasta dan masyarakat. Berdasarkan data dari departemen kelautan dan perikanan tahun 2003, melalui proyek Co-fish melakukan kegiatan rehabilitasi mangrove di Desa Wringinputih Kecamatan Muncar. Pada tahun 2000 dilakukan penanaman magrove dilahan seluas 5 ha, selanjutnya tahun 2001 sebanyak 150.000 mangrove dilahan seluas 30 ha, tahun 2002 sekitar 50.000 mangrove dilahan seluas 10 ha, dan tahun 2003 penanaman dilakukan 
kembali dilahan seluas 30 ha. Berdasarkan data dari dinas kehutanan dan perkebunan kegiatan rehabilitasi mangrove yang pernah dilakukan di Kecamatan Muncar yaitu di Desa Kedungringin (50 ha), Desa Wringinputih (290 ha), dan Desa Kedunggebang (50 ha) serta di kecamatan Tegaldlimo (50 ha). Bibit mangrove yang banyak ditanam adalah dari jenis Rhizophora sp [33]. Mangrove yang ada di bagian Selatan Teluk yaitu di Kecamatan Tegaldlimo merupakan mangrove yang tumbuh alami, lokasinya jauh dari pemukiman penduduk sehingga ancaman dari gangguan aktivitas masyarakat relatif rendah.

Ekosistem mangrove di Teluk pangpang membentuk zonasi, pada zona depan atau berbatasan langsung dengan laut ditemukan jenis Rhizophora mucronata dan Rhizophora apiculata yang berasosiasi dengan Sonneratia alba. Pada stasiun 4 jenis Bruguiera gymnorrhiza ditemukan berasosiasi dengan Rhizophora mucronata. Pada stasiun 8 jenis Xylocarpus moluccensis berasosiasi dengan Rhizophora sp, dan Zona akhir atau dekat dengan daratan ditemukan jenis Excoecaria agallocha, Lumnitzera racemosa, Xylocarpus granatum dan Ceriops tagal. Tipe substrat berpasir dan berlumpur di kawasan Teluk Pangpang diduga sesuai dengan tipe substrat untuk spesies Rhizophora sp sehingga penyebaran buahnya dapat mudah tumbuh dan berkembang dengan baik [26], zona Rhizophora sp biasanya terletak di belakang Avicennia sp dan Sonneratia sp, pada substrat berlumpur lunak [24].

Perbedaan kerapatan mangrove di lokasi penelitian dipengaruhi oleh beberapa faktor, diantaranya mangrove hasil rehabilitasi dengan mangrove yang tumbuh secara alami kerapatannya lebih tinggi pada mangrove hasil rehabilitasi, semakin besar diameter pohon kerapatannya semakin kecil, dan semakin banyak jenis mangrove kerapatannya semakin rendah. Berdasarkan parameter kesesuai ekowisa jenis dan kerapatan mangrove di kawasan Teluk Pangpang dalam kategori sesuai untuk kegiatan ekowisata mangrove.

Tabel 3. Sebaran jenis mangrove di kawasan mangrove Teluk Pangpang

\begin{tabular}{lcccccccc}
\hline \multicolumn{1}{c}{ Jenis mangrove } & \multicolumn{7}{c}{ Stasiun } \\
\cline { 2 - 8 } & 1 & 2 & 3 & 4 & 5 & 6 & 7 & 8 \\
\hline Bruguiera gymnorrhiza & - & - & - & + & - & - & - & - \\
Ceriops tagal & - & - & ++ & - & - & ++ & + & +++ \\
Excoecaria agallocha & - & - & - & + & - & + & - & - \\
Lumnitzera racemosa & - & - & + & + & + & + & - & + \\
Rhizophora apiculata & +++ & +++ & +++ & + & +++ & +++ & +++ & +++ \\
Rhizophora mucronata & + & + & ++ & +++ & + & - & ++ & + \\
Sonneratia alba & + & + & + & + & + & + & + & - \\
Xylocarpus granatum & - & - & - & - & - & - & + & + \\
Xylocarpus moluccensis & - & - & - & - & - & - & - & + \\
\hline
\end{tabular}

Keterangan: (-) tidak ditemukan, (+) sedikit = 1-10 individu, (++) sedang =11-20 individu, (+++) banyak = > 20 individu

Tabel 4. Kerapatan mangrove di kawasan mangrove Teluk Pangpang

\begin{tabular}{lccccccccc}
\hline \multirow{2}{*}{ Jenis mangrove } & \multicolumn{7}{c}{ Tingkat pohon (per stasiun) } \\
\cline { 2 - 9 } & 1 & 2 & 3 & 4 & 5 & 6 & 7 & 8 \\
\hline Bruguiera gymnorrhiza & 0 & 0 & 0 & 2 & 0 & 0 & 0 & 0 \\
Ceriops tagal & 0 & 0 & 8 & 0 & 0 & 11 & 5 & 25 \\
Excoecaria agallocha & 0 & 0 & 0 & 2 & 0 & 1 & 0 & 0 \\
Lumnitzera racemosa & 0 & 0 & 2 & 0 & 2 & 3 & 0 & 1 \\
Rhizophora apiculata & 37 & 43 & 31 & 3 & 41 & 38 & 24 & 42
\end{tabular}




\begin{tabular}{lcccccccc} 
Rhizophora mucronata & 4 & 5 & 10 & 21 & 6 & 0 & 15 & 10 \\
Sonneratia alba & 2 & 2 & 2 & 1 & 3 & 2 & 3 & 0 \\
Xylocarpus granatum & 0 & 0 & 0 & 0 & 0 & 0 & 1 & 4 \\
Xylocarpus moluccensis & 0 & 0 & 0 & 0 & 0 & 0 & 0 & 1 \\
\hline Jumlah & 43 & 50 & 53 & 29 & 52 & 55 & 48 & 83 \\
\hline Total per stasiun $(100 \mathrm{~m})$ & 14 & 17 & 18 & 10 & 13 & 14 & 12 & 17 \\
\hline
\end{tabular}

\section{Pasang Surut}

Berdasarkan data pasang surut yang didapatkan dari badan informasi geospasial (BIG), kondisi pasang surut di kawasan Teluk Pangpang Banyuwangi (Gambar 3). Hasil analisis data tipe pasang surut di Teluk Pangpang yaitu campuran condong ke harian ganda (Mixes semi diurnal tide), hal tersebut menggambarkan bahwa dalam satu hari terjadi dua kali pasang naik dan dua kali pasang surut dengan tinggi muka air laut dan periode yang berbeda.

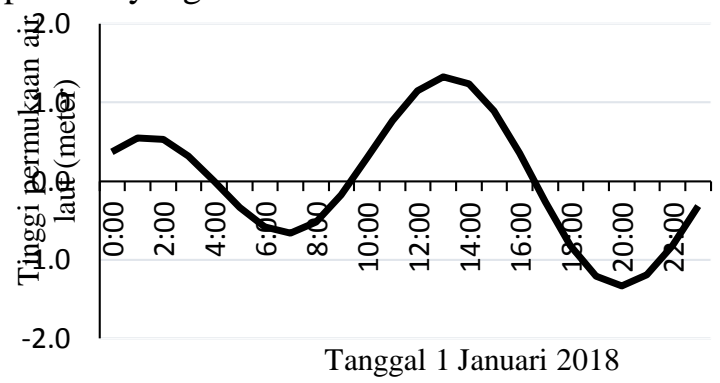

Gambar 3. Kondisi pasang surut di kawasan Teluk Pangpang Banyuwangi

Contoh hasil analisis pasang surut pada tanggal 1 januari 2018 puncak pasang naik pertama pada pukul 01:00 dengan tinggi muka air yaitu 0.459 meter dan pasang surut terendah pada pukul 07:00 yaitu 0.569 meter, selanjutnya tinggi muka air naik kembali dan pada pukul 13:00 adalah puncak pasang naik kedua dengan tinggi muka air laut yaitu 1.325 meter sedangkan pasang surut terendah pada pukul 20:00 yaitu 1.335 meter. Hasil perhitungan data selama tahun 2018 karakteristik elevasi muka air laut rerata (mean sea level, MSL) adalah 0.02 meter. Faktor pembatas kegiatan wisata mangrove diantaranya adalah pasang surut dan faktor musim. Pasang surut mempengaruhi waktu kegiatan wisata khususnya kegiatan berperahu (boating), sedangkan musim sangat menentukan kenyamanan dan keselamatan pengunjung terkait gelombang dan arus air laut [23]. Berdasarkan parameter kesesuai ekowisata mangrove kisaran pasang surut di kawasan Teluk Pangpang adalah kategori sesuai untuk kegiatan ekowisata mangrove.

\section{Potensi Biota}

Kawasan mangrove memiliki potensi yang tinggi untuk pengembangan wisata, di lihat dari keunikan karakteristik tumbuhan penyusun ekosistem mangrove. Daya tarik utama ekosistem mangrove adalah potensi keragaman kehidupan liarnya, terutama burung air, burung migrasi, reptil, mamalia, primata dan ikan [24]. Biota yang menjadi potensi wisata mangrove di lokasi penelitian yaitu burung air, burung migrasi, reptil, krustasea, moluska dan ikan. Spesies burung yang ditemukan (Tabel 5) dan spesies ikan, krustasea, moluska dan reptil (Tabel 6).

Jenis burung air yang banyak di jumpai adalah kuntul kecil, blekok sawah, gajahan, trinil, dara laut, dan berbagai jenis burung air lainnya [25]. Saat musim migrasi yaitu bulan Oktober-Desember sedikitnya terdapat 20 jenis burung migran yang ditemukan di Tanjung Sembulungan dan Teluk Pangpang [9]. Ditemukan udang werus (Litopenaeus vannamei) dengan kelimpahan yang tinggi dan udang windu (Penaeidae) dengan kelimpahan yang lebih rendah. Jenis rajungan (Portunidae pelagicus) ditemukan dalam biomassa yang tinggi, sedangkan jenis kepiting bakau (Scylla serrata) dan udang mantis (Harpiosquilla raphidea) kelimpahan dan biomassanya rendah, hal ini diduga karena penangkapan yang berlebih. Jenis ikan yang ditemukan yaitu dari famili Mugilidae, Leiognathidae, Gobiidae, Clupeidae, Platycephalidae,Centropomidae, Psettodidae, Theraponidae, Polynemidae, Belonidae, 
Sciaenidae, Sillagidae, Squillidae, Penaeidae dan Portunidae. Ditemukan adanya pengelompokan ikan berdasarkan sifat hidupnya yaitu ikan pelagis dan ikan demersal yang menetap dan berkembang biak di kawasan mangrove Teluk Pangpang [26]. Sebaran biota di kawasan mangrove Teluk Pangpang dalam kategori sesuai untuk kegiatan ekowisata mangrove.

Tabel 5. Spesies burung yang ditemukan di kawasan mangrove Teluk pangpang

\begin{tabular}{clll}
\hline \multirow{2}{*}{ No } & \multicolumn{1}{c}{ Nama Lokal } & \multicolumn{1}{c}{ Nama Ilmiah } & Status \\
\cline { 2 - 3 } & \multicolumn{1}{c}{ Kuntul besar } & Egretta alba & LC \\
2 & Kuntul cina & Egretta eulophotes & LC \\
3 & Blekok sawah & Ardeolla speciosa & LC \\
4 & Dara laut & Sterna hirundo & LC \\
5 & Cekakak sungai & Todiramphus chloris & LC \\
6 & Walet & Collocalia vestita & LC \\
7 & Kirik-kirik laut & Merop philippinus & LC \\
8 & Jalak penyu & Acridotheres javanicus & DD \\
9 & Trinil pantai & Actitis hypoleucos & LC \\
10 & Bangau tong tong & Leptoptilos javanicus & VU \\
11 & Gajahan & Numenius sp & LC
\end{tabular}

Keterangan: LC = Least concern (berisiko rendah), DD = Data deficient (informasi kurang), VU = Vulnerable (rentan).

Tabel 6. Biota yang ditemukan di kawasan mangrove Teluk Pangpang

\begin{tabular}{|c|c|c|c|c|c|c|c|c|c|c|}
\hline \multirow{2}{*}{ Jenis } & \multirow{2}{*}{ Nama lokal } & \multirow{2}{*}{ Nama ilmiah } & \multicolumn{8}{|c|}{ Stasiun } \\
\hline & & & 1 & 2 & 3 & 4 & 5 & 6 & 7 & 8 \\
\hline \multirow[t]{3}{*}{ Ikan } & Gelodok/tembakul & Oxudercinae & - & + & + & + & + & + & + & - \\
\hline & Belanak & Moolgarda seheli & - & + & + & + & + & + & + & + \\
\hline & Kerong-kerong & Terapon $\mathrm{sp}$ & - & + & + & + & + & - & + & + \\
\hline \multirow[t]{7}{*}{ Krustasea } & Kepiting bakau & Scylla tranquebarica & - & + & + & + & + & + & + & + \\
\hline & Kepiting bakau jingga & Scylla olivacea & - & + & + & + & + & + & + & + \\
\hline & Kepiting biola & $U c a$ & + & + & + & + & - & - & + & + \\
\hline & Kampat atau ketam & Varuna litterata & + & - & - & + & - & - & - & - \\
\hline & Udang api-api & Metapenaeus sp & - & + & + & - & - & - & - & - \\
\hline & Udang windu & Panaeus monodon & - & + & + & - & - & - & - & - \\
\hline & Udang putih & Panaeus merguensis & - & + & + & - & - & - & - & - \\
\hline \multirow[t]{2}{*}{ Moluska } & Tiram & Crassostrea Gigas & + & + & + & - & - & - & + & + \\
\hline & Kerang bakau & Telescopium sp & + & + & + & - & - & - & + & + \\
\hline Reptil & Biawak & Varanus & - & - & - & - & - & - & + & - \\
\hline
\end{tabular}

\section{Kesesuaian dan Daya Dukung Kawasan}

Kesesuaian kawasan ekowisata mangrove mempertimbangkan lima parameter yaitu ketebalan mangrove, kerapatan mangrove, jenis mangrove, pasang surut, dan obyek biota. Parameter ketebalan mangrove memiliki pengaruh yang sangat tinggi terhadap hasil indeks kesesuaian, berdasarkan 
hasil interpretasi peta Landsat 2018 dan GPS serta pengukuran ketebalan mangrove di lapangan, tingkat ketebalan mangrove sangat beragam, hal tersebut mempengaruhi luasan mangrove. Luasan mangrove yang berbeda antara bagian selatan teluk dengan bagian barat teluk disebabkan oleh berbagai faktor diantaranya pada bagian selatan selain mangrove tumbuh secara alami, jauh dari pemukiman penduduk dan letaknya berada dipaling dalam teluk sedangkan pada bagian barat banyak gangguan dari aktivitas masyarakat dan arus pasang surut juga mempengaruhi vegetasi mangrove yang ada di kawasan tersebut. Data dinas kehutanan dan perkebunan tahun 2003 potensi kawasan mangrove di Desa Wringinputih adalah 375 ha, adanya inisiasi rehabilitasi mangrove terdata pada tahun 2011 luasan mangrove mencapai \pm 226 ha. Sehingga masih ada \pm 149 ha lahan yang perlu dilakukan penanaman mangrove [6].

Indeks kesesuaian ekowisata mangrove berdasarkan parameter kerapatan mangrove, jenis mangrove, pasang surut, dan objek biota dalam kategori sesuai, tetapi secara spasial kategori kesesuaian ekowisata mangrove dalam kategori sesuai dan tidak sesuai (Gambar4).

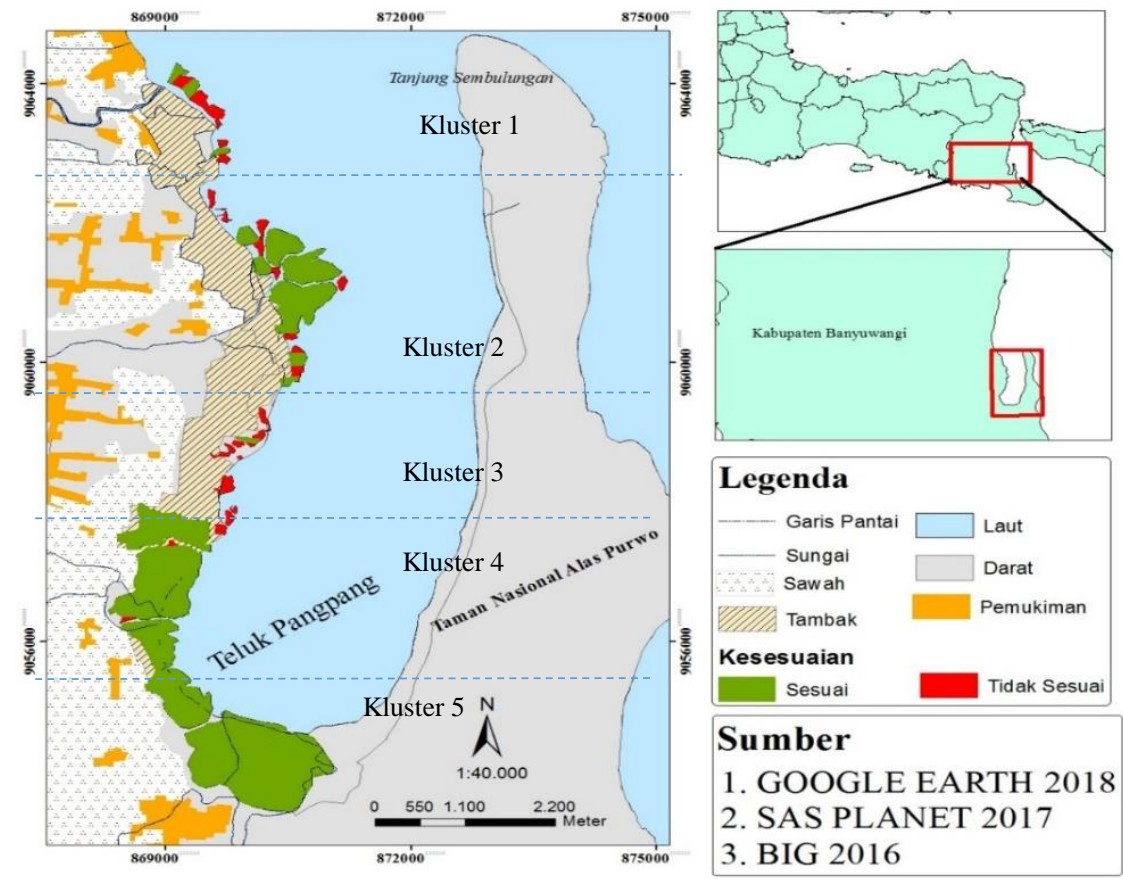

Gambar 4. Peta kesesuaian ekowisata mangrove

Kategori tidak sesuai disebabkan oleh ketebalan mangrove yang relatif tipis pada beberapa titik kawasan, sedangkan kunci utama dari penentuan indeks kesesuaian ekowisata yaitu berdasarkan ketebalan mangrove. Ekosistem mangrove Teluk Pangpang sangat berpotensi untuk dikembangkan sebagai kawasan ekowisata, hal tersebut di dukung oleh beragamnya jenis mangrove dan biota serta burung yang berasosiasi. Untuk menaikkan status kesesuaian berdasarkan ketebalan mangrove dalam kategori tidak sesuai diperlukan upaya penanaman dan rehabilitasi mangrove.

Ketebalan mangrove sangat diperhitungkan terutama pada jenis kegiatan tracking mangrove yang mempengaruhi pembuatan jalur tracking dan daya dukung kawasan untuk menampung pengunjung. Fungsi dari ketebalan mangrove yaitu sebagai pemecah gelombang (breakwater) [27], selain fungsi fisik ketebalan mangrove juga sangat mempengaruhi produksi seresah. Bahan organik dari seresah mangrove merupakan 
mata rantai utama dalam jaring-jaring makanan di ekosistem mangrove [28]. Bahan organik sebagai nutrien bagi pertumbuhan plankton yang dapat meningkatkan keanekaragaman, jumlah individu, dan jumlah jenis ikan [29].

Upaya rehabilitasi/penanaman mangrove dilakukan untuk meningkatkan ketebalan mangrove dan menjaga kelestarian sumberdaya mangrove, hal tersebut harus didukung dengan monitoring dan beberapa hal terkait metode keberhasilan upaya rehabilitasi mangrove. Beberapa tahapan penanaman mangrove dimulai dari persiapan hingga pelaksanaan. Persiapan meliputi pembersihan lahan, pengadaan bibit, penguasaan teknik penanaman, dan perlu diperhatikan formasi jenis penyusunan mangrove pada lokasi yang akan dilakukan penanaman. Setelah program penanaman, kegiatan yang sangat penting adalah pemeliharaan, meliputi penyiangan gulma pengganggu dan penyulaman dilakukan setiap bulan, terutama pada masa pertumbuhan jika ada yang mati [30]. Selain pemilihan bibit mangrove yang akan ditanam kondisi ekologi sangat mempengaruhi pertumbuhan mangrove yaitu kondisi fisika kimia substrat dan perairan, sehingga pemilihan jenis mangrove sangat menentukan keberhasilan penanaman [31]. Keberhasilan upaya rehabilitasi selain teknis terkait bibit mangrove yang akan ditanam yaitu adanya sosialisasi dan koordinasi antar stakeholder dengan melibatkan masyarakat lokal untuk memudahkan pelaksanaan kegiatan penanaman dan pemeliharaan, serta monitoring [32].

Daya dukung kawasan adalah jumlah maksimal pengunjung yang secara fisik mampu ditampung di kawasan yang disediakan pada waktu tertentu tanpa menimbulkan gangguan baik itu pada alam dan manusia [15]. Salah satu langkah untuk mencegah kerusakan kawasan wisata atau kawasan konservasi yang disebabkan oleh tingginya wisatawan yang berkunjung yaitu dengan mengetahui daya dukung kawasan wisata. Dengan mengetahui daya dukung kawasan dapat digunakan untuk meminimalkan dampak yang ditimbulkan akibat jumlah pengunjung yang melebihi kapasitasnya, dengan harapan objek dan daya tarik wisata dapat terjaga kelestariannya [12].

Tabel 7. Daya dukung kawasan mangrove Teluk Pangpang untuk ekowisata

\begin{tabular}{|c|c|c|}
\hline Kluster mangrove & $\begin{array}{l}\text { Panjang Area yang sesuai atau } \\
\text { potensi ekologis }(\mathrm{Lp})(\mathrm{m})\end{array}$ & DDK (Orang/hari) \\
\hline Kluster 1 & 485 & 10 \\
\hline Kluster 2 & 4269 & 85 \\
\hline Kluster 3 & 279 & 6 \\
\hline Kluster 4 & 6096 & 122 \\
\hline Kluster 5 & 5794 & 116 \\
\hline Total & & 339 \\
\hline
\end{tabular}

Daya dukung untuk kegiatan tracking mangrove berdasarkan ketebalan mangrove yang sesuai menampung pengunjung sebanyak 339 orang/hari (Tabel 7). Kondisi nyata saat ini di lokasi penelitian yaitu jalur tracking mangrove masih berupa titik spot pada masing-masing Desa dan belum terhubung dalam satu kawasan, sehingga nantinya jumlah daya dukung wisatawan dapat bertambah jumlahnya jika jalur tracking terkoneksi dan ketebalan mangrove yang bertambah tebal sesuai dengan parameter kategori kesesuaian.

Saat ini terdapat 5 titik jalur tracking yaitu 3 titik di Kecamatan Muncar dan 2 titik di Kecamatan Tegaldlimo yang dibuat oleh masing-masing pengelola. Terdapat perbedaan karakteristik objek wisata selain vegetasi mangrove yang ditawar pada kelima titik tersebut dan pengunjung mendominasi untuk 
datang berkunjung pada titik lokasi di Kecamatan Muncar hal tersebut mendorong pengelola untuk terus menambah jalur tracking karena jumlah pengunjung yang memenuhi sepanjang jalur tracing yang ada, sedangkan menurut Yulianda jarak antar pengunjung adalah 50 meter dengan asumsi pengunjung tidak saling mengganggu atau ataupun terganggu dengan aktivitas pengunjung yang lain [15].

\section{KESIMPULAN}

Kesimpulan dari penelitian yaitu, kawasan mangrove Teluk Pangpang memiliki 9 jenis mangrove dan berbagai biota akuatik serta burung air yang berasosiasi membentuk ekosistem. Terdapat sedikitnya 20 spesies burung migran yang singgah pada musim migrasi, selain itu terdapat beberapa jenis burung yang statusnya dilindungi.

Kesesuaian ekowisata mangrove berdasarkan kerapatan mangrove, jenis mangrove, pasang surut dan objek biota dalam kategori sesuai, tetapi secara spasial kategori kesesuaian ekowisata mangrove di Teluk Pangpang dalam kategori sesuai dan tidak sesuai. Daya dukung kawasan untuk jenis kegiatan tracking mangrove adalah 339 orang/hari.

\section{DAFTAR PUSTAKA}

[1] P. J. Hogarth. The Biology of Mangrove. Oxford University Press. Oxford. 1999.

[2] D. G. Bengen. Sinopsis Ekosistem dan Sumberdaya Alam Pesisir dan Lautan. Pusat Kajian Sumberdaya Pesisir dan Lautan. Institut Pertanian Bogor. Bogor. 2001.

[3] E. B. Barbier, S. D. Hacker, C. Kennedy, E. W. Koch, A. C. Stier, and B. R. Silliman, "The value of estuarine and coastal ecosystem services," Ecological monographs., vol. 81, no. 2, hal. 169-193, May 2011.
[4] U. S. Paul, and H. Schneider, "Mangrove Dynamics and management in North Brazi," Ecological studies 211., hal. 3-7, 2011.

[5] Sulastini D. Seri Buku Informasi dan Potensi Mangrove Taman Nasional Alas Purwo. Balai Taman Nasional Alas Purwo. Banyuwangi. 2011.

[6] A. B. Raharja. Pengelolaan Wilayah Pesisir Teluk Pangpang untuk Efisiensi Penataan Ruang Berbasis Spasial [Tesis]. Bogor (ID): Institut Pertanian Bogor. 2014.

[7] W. Neka, W. Ervina, dan A. Chairil. Ringkasan Eksekutif Kajian Potensi Hutan Mangrove dalam Pengembangan Ekonomi Masyarakat Pesisir di Teluk pangpang. Banyuwangi. 2013.

[8] E. V. Setyaningrum, "Area development model base on mangrove wetland essential ecosystem, in Pangpang Bay Banyuwangi Indonesia," Journal of resources development and management., vol. 18, hal. 93-99, 2016.

[9] M. J. Grantham, "Birds of alas purwo national park, Eats Java," Kukila 11., hal. 97-121, Mar 2000.

[10] F. Yulianda, F. Achmad, A. Luky, A. H. Armin, H. Sri, Kusharjani, dan S. K. Ho. Pengelolaan pesisir dan laut secara terpadu. Korea International Cooperation Agency (KOICA). 2010.

[11] P. N. Sadikin, H. S. , Arifin, B. Pramudya, dan S. Mulatsih, "Carrying capacity preserve biodiversity on ecotourism in Mount Rinjani National Park, Indonesia," Biodiversity., vol. 18, no. 3, hal. 978-989, Jul 2017.

[12] H. Purnomo, B. Sulastyantara, dan A. Gunawan, "Peluang usaha ekowisata di kawasan cagar alam Pulau Sempu, Jawa Timur," Jurnal penelitian sosial 
dan ekonomi kehutanan., vol. 10, no. 4, hal. 247-263, Des 2013.

[13] L. Hakim, D. Siswanto, and N. Nakagoshi, "Mangrove concervation in East Java: the ecotourism development perspectives," The journal of tropical life science., vol. 7, no. 3, hal. 277-285, Sep 2017.

[14] M. Honey. Ecotourism and sustainable development. Who owns paradise? Island Press, Washington D.C. 1999.

[15] F. Yulianda. Ekowisata bahari sebagai alternatif pemanfaatan sumberdaya pesisir berbasis konservasi. Makalah Seminar Sains 21 Februari 2007. Departemen Manajemen Sumberdaya Perairan, FPIK IPB. Bogor. 2007.

[16] P. N. Sadikin, H. S. Arifin, B. Pramudya, and S. Mulatsih, "Carrying capacity preserve biodiversity on ecotourism in Mount Rinjani National Park, Indonesia," Biodiversity., vol. 18, no. 3, hal 978-989, Jul 2017.

[17] A. Romadhon, F. Yulianda, D. Bengen, and L. Adrianto, "Sustainable tourism based on carrying capacity and ecological footprint at Sapeken Archipelago, Indonesia," International journa of ecosystem., vol. 4, no. 4, hal. 190-196, 2014.

[18] C. Kusmana, Istomo, C. Wibowo, S. W. Budi, I. Z. Siregar, T. Tiryana, dan S. Sukardjo. Manual Silvikultur Mangrove di Indonesia. KOREA INTERNASIONAL COOPERATION AGENCY (KOICA): The rehabilitation Mangrove Forest and Coastal Area Damage By Tsunami in Aceh Project. 2008.

[19] Y.R. Noor, M. Khazali, dan N. N. Suryadiputra. Panduan Pengenalan Mangrove di Indonesia. Bogor (ID): A Appraisal Technique for Fisheries FAO
Fisheries Circular No. 947. Rome. 2006.

[20] A. Sofian, N. Harahab, dan Marsoedi. Kondisi dan Manfaat langsung Ekosistem Hutan mangrove Desa Penunggul Kecamatan Nguling Kabupaten Pasuruan. Vol. 2, no. 2, hal. 56-63. PSP UB. Malang. 2012.

[21] Sudarmadji, dan Indarto, "Identifikasi lahan dan potensi hutan mangrove di bagian timur Propinsi Jawa Timur," Bonorowo Wetlands., vol. 1, no. 1, hal. 31-36, Jun 2011.

[22] Y. R. Buwono, "Identifikasi dan kerapatan ekosistem mangrove di kawasan Teluk Pangpang Kabupaten Banyuwangi,” Samakia: Jurnal Ilmu Perikanan., vol. 8, no. 1, hal. 32-37, Apr 2017.

[23] Bahar A. Kajian kesesuaian dan daya dukung ekosistem mangrove untuk pengembangan ekowisata di Gugus Pulau Tanakeke Kabupaten Takalar, Sulawesi Selatan. [Tesis]. Bogor (ID): Institut Pertanian Bogor. 2004.

[24] D. G. Bengen. Pedoman teknis pengenalan dan pengelolan ekosistem mangrove. Bogor: Pusat kajian sumberdaya pesisir dan lautan IPB. 2000 .

[25] R. T. Nugraha. Seri buku informasi potensi burung air Taman Nasional Alas Purwo. Banyuwangi: Balai Taman Nasional Alas Purwo. 2011.

[26] Y. R. Buwono, I. P. G. Ardhana, dan M. Sudarma, "Potensi fauna akuatik ekosistem hutan mangrove di kawasan Teluk Pangpang Kabupaten Banyuwangi," Ecotrophic: Jurnal Ilmu Lingkungan., vol. 9, no. 2, hal. 23-33, 2015. 
[27] R. Sawitri, M. Bismark, dan E. Karlina, "Ekosistem mangrove sebagai obyek wisata alam di kawasan konservasi mangrove dan bekantan di Kota Tarakan," Jurnal penelitian hutan dan konservasi alam., vol. 10, no. 3, hal. 297-314, Des 2013.

[28] G. R. Aida, Y. Wardiatno, A. Fahrudin, dan M. M. Kamal, "Produksi seresah mangrove di pesisir Tangerang, Banten," Jurnal Ilmu Pertanian Indoneisa (JIPI)., vol. 19, no. 2, hal. 91-97, Ags 2014.

[29] R. Descasari, I. Setyobudiandi, dan R. Affandi, "Keterkaitan ekosistem mangrove dengan keanekaragaman ikan di Pabean Ilir dan Pagirikan, Kabupaten Indramayu, Jawa Barat," Bonoworo wetlands., vol. 6 , no. 1, hal. 43-58, Jun 2016.

[30] Pramudji, "Upaya pengelolaan rehabilitasi dan konservasi pada lahan mangrove yang kritis kondisinya," Oseana., vol. 26, no. 2, hal. 1-8, 2001.

[31] B. Brown, dan R. R. Lewis. Five steps to successful ecological restoration of mangroves. Lewis $\mathrm{R}$ et al (Eds) Yogyakarta, Indonesia: Yayasan Akar Rumput Laut (YARL) and the mangrove action project. 2006.

[32] Y. Mayalanda, F. Yulianda, dan I. Setyobudiandi, "Strategi rehabilitasi ekosistem mangrove melalui analisis tingkat kerusakan di Suaka Margasatwa Muara Angke, Jakarta," Bonoworo wetlands., vol. 4, no. 1, hal. 12-36, Jun 2014.

[33] M, Nazili. Strategi pengelolaan ekosistem mangrove berbasis partisipasi masyarakat di kawasan mangrove Teluk PangpangBanyuwangi [Tesis]. Bogor (ID): Sekolah Pasca Sarjana, Institut Pertanian Bogor. 2004. 